\title{
Changes in private car ownership associated with car sharing: gauging differences by residential location and car share typology
}

\author{
Taru Jain $^{1}$ (D) $\cdot$ Geoffrey Rose ${ }^{1} \cdot$ Marilyn Johnson $^{1}$
}

Accepted: 15 February 2021 / Published online: 4 March 2021

(C) The Author(s), under exclusive licence to Springer Science+Business Media, LLC part of Springer Nature 2021

\begin{abstract}
While a large body of literature shows that car share encourages low car ownership, the evidence is rather limited in the context of different types of car share (fleet-based versus peer-to-peer) and geographic settings (inner versus middle suburbs). This study was an indepth investigation of the impact of (round-trip) car share on ownership, including forgone or delayed purchasing across different car share systems. An online survey was conducted with car share members $(n=651)$ and non-members $(n=290)$ in Melbourne, Australia. All respondents had a shared car available within a 10-min walk of their home. The first part of the paper compared member and non-member householders (socio-demographically and geographically adjusted) and found that members owned significantly fewer cars than non-members. In the second part of the paper, a quasi-longitudinal comparison of car share members was conducted. One in three households reduced car ownership, and most reductions occurred in the year prior to joining car share. Fleet-based car share members reported a larger reduction in car ownership compared to peer-to-peer car share members. Residents of inner and middle suburbs of Melbourne reported similar "net" reductions in car ownership, the reasons differed. Residents in densely populated inner suburbs used car share to avoid or delay car ownership while middle suburb residents used car share to avoid purchasing a second car. Findings provide valuable insights for transport policy settings which have the potential to influence car share availability and thereby support broader policy objectives to reduce dependency on private car ownership and use.
\end{abstract}

Keywords Carsharing - Car ownership · Peer to peer · Travel behaviour - Shared mobility · Impact $\cdot$ Sustainability

Taru Jain

tarujain84@gmail.com

1 Department of Civil Engineering, Monash University, Melbourne, VIC, Australia 


\section{Introduction}

Over the past seven decades, private car ownership and use have increased rapidly. In Australian cities, total passenger travel has risen ten-fold in that period, and most of this increase $(87 \%)$ can be attributed to private road vehicles (Bureau of Infrastructure and Regional Development (BITRE) 2015). The externalities associated with automobile dependence include pressing issues such as traffic congestion, climate change, local air quality and health impacts (Parry et al. 2007). In 2015, the avoidable social cost of congestion in Melbourne alone was A $\$ 4.6$ billion, forecast to more than double in the next decade (A $\$ 10.2$ billion by 2030 BITRE 2015). In addition to the economic case for reducing autodependency, the transport sector is responsible for almost a quarter of greenhouse emissions (23\%), of which 71 per cent is attributable to road transport (Sims et al. 2014). Given car use is closely associated with car ownership (Kitamura 1989; Van Acker and Witlox 2010), systems and technologies which offer an alternative to private car ownership will have broad community benefits.

Car share has emerged as a mobility option which allows its members to gain short term rental access to a car for periods by time (starting at $30 \mathrm{~min}$ ). Car share operators charge for usage by kilometre and by time. Car share differs from traditional car rentals as bookings can be made for much shorter periods of time whereas car rentals are mainly booked for a minimum of $24 \mathrm{~h}$. Additionally, car share vehciles can be accessed by the users directly through cards/key and do not require them to visit a booking office, as in the case of a car rental. As private cars are only used for ten per cent of the day (Shoup 1997), car share is a cost-efficient service which separates the fixed cost of car ownership (e.g. car purchase price, insurance, registration etc.) from the running costs (e.g. fuels, tolls etc.). So, while car share users pay the full operating costs, they only pay a portion of the fixed costs, based on the duration of use.

Car share services emerged in Europe, gained popularity in North America and are now increasingly available in the Asia-Pacific region (Shaheen and Cohen 2012, 2007). The type of car share services available is also evolving. Early variants were primarily fleetbased round trip services where operator-owned shared cars could be rented from designated locations and had to be returned to the same location. These are also known as the business to consumer (B2C) car share model (Münzel et al. 2019). More recently, peer-topeer $(\mathrm{P} 2 \mathrm{P})$ services have emerged where private car owners can rent their cars through an operator who manages bookings and payments. The most recent variant of car share is the one-way system where the pick-up and drop-off location can be different, allowing oneway bookings (Becker et al. 2017). This study focuses on round trip car share where the cars are parked at designated pods from where they can be borrowed by members but must be returned to the same location.

This paper is part of a larger research project examining adoption and impacts of round trip car share (Jain 2020; Jain et al. 2020). The study used a mixed-methods approach where qualitative insights (published in Jain et al. (2020)) informed the quantitative surveys reported in this paper; providing a rich methodological perspective to the impacts of car share.

The remainder of this paper is organised as follows. "Literature review" section presents a review of the literature. The local context of the study area is described in "Research context. "Method" section details the methodology adopted for the study. Section Results details the key findings of the research. The paper concludes following a discussion of the findings in "Discussion and conclusion" section. 


\section{Literature review}

There is a consensus in the literature that car share use is associated with a net reduction in car ownership levels (Stasko et al. 2013; Martin and Shaheen 2011a, b; Cervero and Tsai 2004; Lane 2005; Martin et al. 2010). However, findings vary widely across cities and by a range of factors including study methodology used, study period, geographic context, car sharing service characteristics and potential differences in social and cultural norms about mobility. While some studies compare members with non-members, others have compared car ownership levels for members, before and after joining car share.

\section{Comparisons of private car ownership between car share members and non-members}

Previous research suggests car share members own fewer private cars than non-members (see "Appendix A"). Sioui et al. (2013) reported most car share members (88\%) were zerocar households compared to only a third (34\%) of non-members. In a longitudinal study, reductions in the number of motor vehicles owned did not differ substantially for members compared to non-members. However, members were less likely to buy additional vehicles (Cervero 2003; Cervero and Tsai 2004; Cervero et al. 2007). Clewlow (2016) reported that differences in car ownership between members and non-members were only notable in high residential density areas, suggesting an association with the built form, transit accessibility and availability of parking.

However, 80 per cent of the observed difference in motor vehicle ownership between car share members and non-members could be attributed to self-selection bias pertaining to socio-economic and demographic characteristics, residential location choices, and attitudes (Mishra et al. 2015). Car sharers are more likely to be younger, highly educated, have smaller households and earn higher incomes than the typical population (Martin et al. 2010; Burkhardt and Millard-Ball 2006; Celsor and Millard-Ball 2007; Becker et al. 2017). They are also more likely to live in dense urban areas with good public transport (MillardBall 2005) and, compared to non-members, are more environmentally aware and are more willing to try new technology (Efthymiou and Antoniou 2016).

Some researchers have accounted for bias. Cervero and Tsai (2004), Cervero et al. (2007) selected a control group from people willing to join car share but who did not have access to passively account for differences in attitudes. However, groups may have varied by location. Mishra (2015) used propensity score matching based on socio-demographic characteristics, residential and job location, and built environment to compare car sharers with comparable non-sharers from census data. Clewlow (2016) also used census data set to select non-members with at least one shared car available to account for car share availability. With the exception of Mishra (2015), studies only account for one form of bias at a time. There is a need for better study methodologies to account for multiple sources of bias and to separate the impact of car share from other factors such as residential location, access to car share, socio-demographic factors and attitudes.

\section{Changes in private car ownership for car share members}

Changes in private car ownership are also accounted for in car share studies. Before and after comparisons typically compare members' car ownership at the time of joining car share and a point in the future to calculate the change in car ownership since joining car 
share (see "Appendix B"). Some studies also include forgone purchases, where members decided not to go ahead with a planned or intended car purchase (Martin and Shaheen 2011b).

The number of private cars replaced per shared car ranges from five (Millard-Ball 2005) to 23 (Lane 2005), with greater reductions reported when forgone car purchases are included (Martin et al. 2010). The percentage of members forgoing car purchase is consistently higher than members who reduce car ownership (Cervero 2003; Cervero and Tsai 2004; Katzev et al. 2001; Huwer 2004). As a large percentage of car share members do not own a vehicle (Sioui et al. 2013), forgone purchases must be included to gauge the full impact of car sharing, as to focus only on the observed impact is likely to be misleading.

A major limitation of before and after studies which begin at the time of joining car share is that this approach does not account for car ownership reductions in the period before joining car share. Recent qualitative research identified that many car share members sold a car in the year before joining car share (Jain et al. 2020). Inclusion of the period before joining car share (e.g. up to one year prior) is essential to understanding the nuanced changes in private car ownership. However, to date, there has been limited attention in the pre-car share period.

In terms of impact studies, most research has focused on fleet-based systems with limited attention on P2P (Dill et al. 2017) and no studies comparing the two systems. While only one study has compared impact by geographical location (Clewlow 2016). To inform effective practice and policy action to maximise the use of car share, it is important to understand if car share is as effective in reducing car ownership in medium to low-density areas, as it is in high-density areas.

Given the knowledge gaps identified above, the key objectives of this study were to examine:

- differences in car ownership between car share members and non-members, accounting for multiple confounding factors.

- car ownership decisions of car share members and how they vary for:

- P2P and fleet-based car share members

- residents of inner and outer suburbs

\section{Research context}

While car sharing services have been growing worldwide since the1970s (Shaheen et al. 1998), they only entered Australia in 2004. Although slow to take off (Shaheen and Cohen 2007), Australian car share systems are gathering momentum. As of 2018, there are over 4000 shared cars available in Australia, mainly concentrated in Sydney and Melbourne (Flexicar 2017; Goget 2017; Car Next Door 2017). This approximately translates to 190 shared cars per million urban population in Australia (in the year 2017) which is much less when compared to 1294 shared cars per million urban population in the UK (in the year 2009) and 2174 in Germany (in the year 2009). ${ }^{1}$ On the other hand, the numbers are much

\footnotetext{
1 Calculated by author based on car sharing figures available from Loose et al. (2010) and publicly available urban population data for the respective countries.
} 


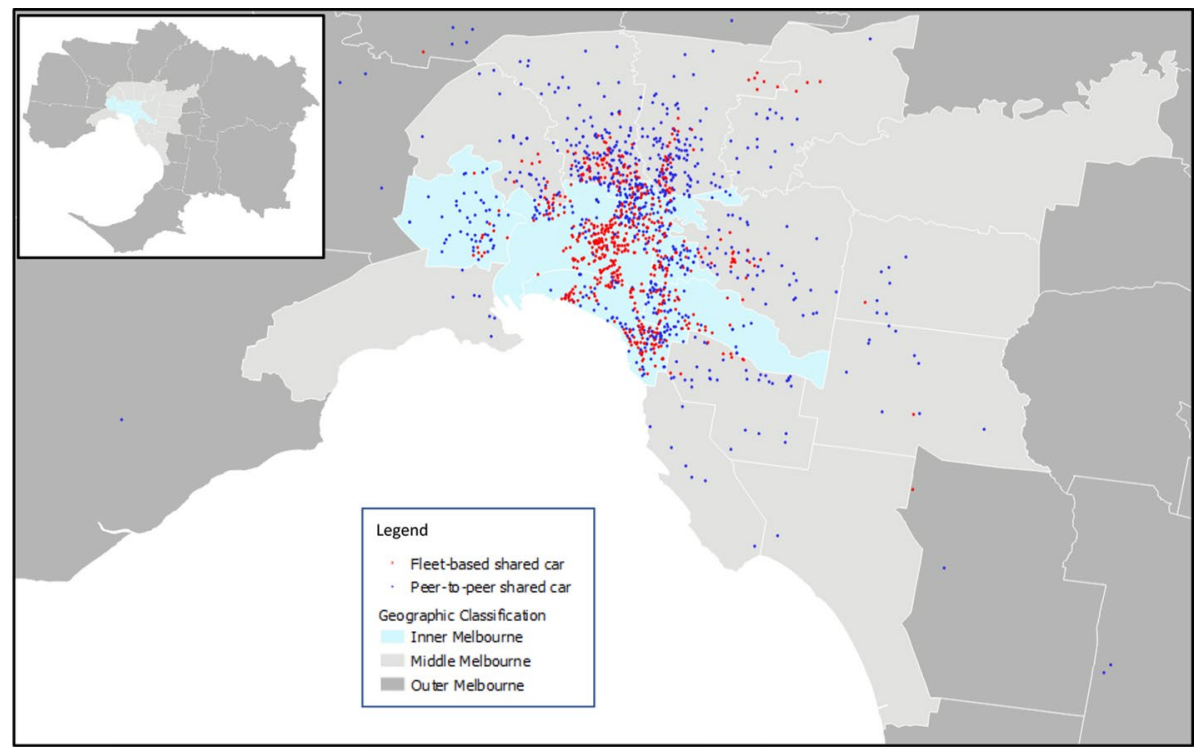

Fig. 1 Location of fleet-based and peer-to-peer shared cars in inner, middle and outer Melbourne

closer to those in the USA (55 shared cars per million urban population, excluding P2P cars) and Canada (293 shared cars per million urban population, excluding P2P cars). ${ }^{2}$

Melbourne has a third of the shared cars in Australia with over 1500 cars available across inner and middle Melbourne and operated by five fleet-based car share providers (CSPs) and two peer-to-peer (P2P) CSPs. The majority of Melbourne's shared cars (65\%) are located in the five inner local council areas of Melbourne with the remainder located in the middle (34\%) and outer (1\%) suburbs, which compared to the inner-city areas, have a lower population density (see Fig. 1).

\section{Method}

This study was an online survey conducted with current, active car share members and non-members. The survey took approximately 20 -min to complete and was delivered using Qualtrics. The research protocol was approved by the Monash University Human Research Ethics Committee (Project 13,024).

\section{Recruitment}

Participants were recruited via an email invitation to all members by three of the largest car share organisations in Melbourne (two fleet-based, one P2P). An invitation to participate

\footnotetext{
${ }^{2}$ Calculated by author based on car sharing figures available from Shaheen and Cohen (2020) and publicly available urban population data for the respective countries.
} 
was also disseminated through social media and a market research company to increase the sample size and recruit non-members.

Recruitment exclusion criteria were:

- less than 18 years of age

- did not have a valid driving licence

- inactive car share members had not made a booking in the past 12 months

- ex-car share members

- car share members with corporate memberships

- non-members who did not have a shared car available within a 10-min walking distance from their primary residence

Respondents under 18 and without a driving licence were screened out because they did not have an option to drive and own a car, hence they were not of interest to this study. Inactive car share members had held the membership but since they had not used car share, it was considered unlikely that the membership had an impact on their car ownership. It is possible that having the car share membership as a safety net helped them avoid the purchase of an additional car, but for the purpose of this paper, that angle was not explored. Car share members with corporate memberships were excluded because it was not known if such memberships were used to book cars for personal purposes.

All members and non-members were asked about current mobility behaviour and car ownership. Analysis was conducted as two studies. In Study 1, car ownership of members and non-members were compared, after applying layers of geographic and socio-demographic adjustments. In Study 2, car ownership changes among car share members were traced using a quasi-longitudinal method. Questions to members included household car ownership levels at one year prior to joining car share, at joining car share and at the time of the survey. The duration of one year prior to joining car share was informed by earlier research (Jain et al. 2020). Members who reported no change in car ownership between joining car share and the survey, were asked if they would have purchased an additional car if car sharing was not available. Members were also asked about their intention to increase car ownership in the next few years.

\section{Response rate}

Many previous studies have collaborated with car share operators to survey members. Recruiting non-members is a challenge, and since sampling frames of them are not available, convenience sampling is a common approach, and consequently, results need to be interpreted cautiously. The response rates for the two groups could not be ascertained. For car share members as recruitment was via an invitation from car share operators, the number of members contacted is unknown. For non-members, the survey requests were posted via social media. While the method was useful in the recruitment of participants, it is not possible to know how many people viewed the posts on social media platforms. It is important to reiterate that to be included in the study; non-members needed to have a car share vehicle available within a 10-min walking distance from their home. This is so that all participants (members and non-members) had an option to access a shared car and also lived in comparable built environment.Data for members and non-members was analysed using SPSS and the results are discussed in the following section. 


\section{Results}

In total, 941 completed and valid responses were received $(n=651$ car share members; $\mathrm{n}=290$ non-members). Of the member respondents, 317 were P2P car share members, 237 were fleet-based car share members and 97 were members of both types car share. The proportion of members and non-members was similar in inner $(n=441)$ and middle $(n=210)$ Melbourne. Respondents differed by gender across the two groups, half the members were male, and almost two-thirds of non-members were female (see Table 1). Members were more likely to be more highly educated and full-time workers compared to non-members. Member households were more likely to be zero-car owners compared to non-member households. There were no major differences between members and non-members in terms of household composition. Socio-demographic details of respondents are shown in Table 1.

Based on data shown in Table 1, statistical tests confirmed significant differences between members and non-members when considering gender (Pearson ChiSquare $=21.285, \quad p<0.001)$, age (Pearson Chi-Square $=162.546, \quad p<0.001)$, education (Person Chi-Square $=33.820, p<0.001$ ), employment status (Pearson chi Square $=123.457, p<0.05)$, household income $($ Pearson Chi-Square $=25.815, p<0.05)$ and household type (Pearson Chi-Square $=28.465, p<0.001$ ).

\section{Study 1- Comparing car ownership of members and non-members}

A staged data analysis approach was used to control for socio-demographic and geographic factors in comparisons of car ownership between members and non-members. In the first stage (Table 2), household private car ownership level in inner and middle Melbourne were compared between car share member households (column 2) and census averages (column 3 ). In both inner and middle Melbourne, the mean car ownership levels of members were less than half that of the census households.

Census households are distributed across a given geographic area. However, car share is concentrated in areas of high density with good public transport access (de Lorimier and El-Geneidy 2013; Millard-Ball 2005). As differences in car ownership between car share members and general census households could be associated with geographic characteristics, it was not appropriate to directly compare car share members with the census population. A more geographically comparable sample of non-members was needed.

\section{Applying a geographic control}

The average car ownership for the geographically controlled non-member sample was significantly higher than the member averages in both inner $(p<0.001)$ and middle $(p<0.001)$ Melbourne. ${ }^{3}$ However, differences were less pronounced than those between members and general census data.

\footnotetext{
${ }_{3}^{3}$ As car ownership data for members and non-members had a non-normal distribution, a Mann Whitney U test, the non-parametric equivalent of a $\mathrm{T}$ test, was conducted to compare mean car ownership for the two independent samples.
} 
Table 1 Socio-demographic characteristics of survey respondents

\begin{tabular}{|c|c|c|c|c|c|c|}
\hline \multirow[t]{2}{*}{ Category } & \multicolumn{2}{|c|}{ Member $n=651$} & \multicolumn{2}{|c|}{$\begin{array}{l}\text { Non-member } \\
n=290\end{array}$} & \multicolumn{2}{|c|}{ Total $n=941$} \\
\hline & $\mathrm{n}$ & $\%$ & $\mathrm{n}$ & $\%$ & $\mathrm{n}$ & $\%$ \\
\hline \multicolumn{7}{|l|}{ Gender } \\
\hline Female & 314 & 48.2 & 185 & 63.8 & 499 & 53.0 \\
\hline Male & 332 & 51.0 & 101 & 34.8 & 433 & 46.0 \\
\hline Non-binary & 5 & 0.8 & 4 & 1.4 & 9 & 1.0 \\
\hline \multicolumn{7}{|l|}{ Location } \\
\hline Inner Melbourne & 441 & 67.7 & 182 & 62.8 & 623 & 66.2 \\
\hline Middle & 210 & 32.3 & 108 & 37.2 & 318 & 33.8 \\
\hline \multicolumn{7}{|l|}{ Age } \\
\hline $18-24$ & 52 & 8.0 & 8 & 2.8 & 60 & 6.3 \\
\hline $25-34$ & 290 & 44.5 & 65 & 22.4 & 355 & 37.3 \\
\hline $35-44$ & 179 & 27.5 & 52 & 17.9 & 231 & 24.3 \\
\hline $45-54$ & 77 & 11.8 & 51 & 17.6 & 128 & 13.5 \\
\hline $55-64$ & 39 & 6.0 & 59 & 20.3 & 98 & 10.3 \\
\hline $65-74$ & 13 & 2.0 & 46 & 15.9 & 59 & 6.2 \\
\hline 75 and above & 1 & 0.2 & 9 & 3.1 & 10 & 1.1 \\
\hline \multicolumn{7}{|l|}{ Education } \\
\hline Postgraduate Degree & 253 & 38.9 & 80 & 27.6 & 333 & 35.4 \\
\hline Bachelor Degree & 284 & 43.6 & 118 & 40.7 & 402 & 42.7 \\
\hline Year 12 or below & 34 & 5.2 & 41 & 14.1 & 75 & 8.0 \\
\hline Cert III, Cert IV, Diploma & 80 & 12.3 & 51 & 17.6 & 131 & 13.9 \\
\hline \multicolumn{7}{|l|}{ Employment Status } \\
\hline Employed full-time & 436 & 67.0 & 130 & 44.8 & 566 & 60.1 \\
\hline Employed part time & 100 & 15.4 & 62 & 21.4 & 162 & 17.2 \\
\hline Student & 72 & 11.1 & 15 & 5.2 & 87 & 9.2 \\
\hline Retired & 11 & 1.7 & 53 & 18.3 & 64 & 6.8 \\
\hline Unemployed looking for work & 15 & 2.3 & 16 & 5.5 & 31 & 3.3 \\
\hline Other (e.g. At home care-giver) & 17 & 2.6 & 14 & 4.8 & 31 & 3.3 \\
\hline \multicolumn{7}{|l|}{ Household income } \\
\hline Not answered & 4 & 0.6 & 9 & 3.1 & 13 & 1.4 \\
\hline$\$ 1-\$ 499$ & 29 & 4.5 & 26 & 9.0 & 55 & 5.8 \\
\hline$\$ 500-\$ 799$ & 52 & 8.0 & 33 & 11.4 & 85 & 8.9 \\
\hline$\$ 800-\$ 1499$ & 163 & 25.0 & 52 & 17.9 & 215 & 22.6 \\
\hline$\$ 1500-\$ 2499$ & 183 & 28.1 & 75 & 25.9 & 258 & 27.1 \\
\hline$\$ 2500-\$ 3999$ & 143 & 22.0 & 56 & 19.3 & 199 & 20.9 \\
\hline Above $\$ 4000$ & 62 & 9.5 & 28 & 9.7 & 90 & 9.5 \\
\hline \multicolumn{7}{|l|}{ Household type } \\
\hline Couple with no children & 230 & 35.3 & 97 & 33.4 & 327 & 34.8 \\
\hline Single person & 167 & 25.7 & 71 & 24.5 & 238 & 25.3 \\
\hline Couple with one or more children under 18 & 122 & 18.7 & 52 & 17.9 & 174 & 18.5 \\
\hline Group of unrelated adults & 106 & 16.3 & 27 & 9.3 & 133 & 14.1 \\
\hline Group of related adults & 26 & 4.0 & 33 & 11.4 & 59 & 6.3 \\
\hline Single parents & 0 & 0.0 & 10 & 3.4 & 10 & 1.1 \\
\hline
\end{tabular}


Table 1 (continued)

\begin{tabular}{|c|c|c|c|c|c|c|}
\hline \multirow[t]{2}{*}{ Category } & \multicolumn{2}{|c|}{ Member $n=651$} & \multicolumn{2}{|c|}{$\begin{array}{l}\text { Non-member } \\
\mathrm{n}=290\end{array}$} & \multicolumn{2}{|c|}{ Total $n=941$} \\
\hline & $\mathrm{n}$ & $\%$ & $\mathrm{n}$ & $\%$ & $\mathrm{n}$ & $\%$ \\
\hline \multicolumn{7}{|c|}{ Household car ownership } \\
\hline 0 & 394 & 60.5 & 30 & 10.3 & 424 & 45.1 \\
\hline 1 & 194 & 29.8 & 158 & 54.5 & 352 & 37.4 \\
\hline $2+$ & 63 & 9.7 & 102 & 35.2 & 165 & 17.5 \\
\hline
\end{tabular}

Table 2 Comparison of average household car ownership for car share members and non-members

\begin{tabular}{|c|c|c|c|c|c|c|}
\hline \multirow{2}{*}{$\begin{array}{l}\text { Geographic location of } \\
\text { respondents }\end{array}$} & \multicolumn{3}{|c|}{ No. of respondents } & \multicolumn{3}{|c|}{ Average car ownership per household } \\
\hline & Members & Non-member & Member & $\begin{array}{l}\text { Census } \\
\left(\mathrm{SA} 2^{\mathrm{a}} \text { aver- }\right. \\
\text { age })\end{array}$ & $\begin{array}{l}\text { Non-member } \\
\text { (unadjusted) }\end{array}$ & $\begin{array}{l}\text { Non- } \\
\text { member } \\
\text { (weighted) }\end{array}$ \\
\hline Inner Melbourne, $n=627$ & 441 & 186 & 0.44 & $1.29^{\mathrm{b}}$ & $1.25^{\mathrm{b}}$ & $1.22^{\mathrm{b}}$ \\
\hline Middle Melbourne, $\mathrm{n}=302$ & 210 & 92 & 0.67 & $1.69^{\mathrm{b}}$ & $1.45^{\mathrm{b}}$ & $1.20^{\mathrm{b}}$ \\
\hline Total respondents, $n=929$ & 651 & 278 & 0.52 & $1.56^{\mathrm{b}}$ & $1.32^{\mathrm{b}}$ & $1.21^{\mathrm{b}}$ \\
\hline
\end{tabular}

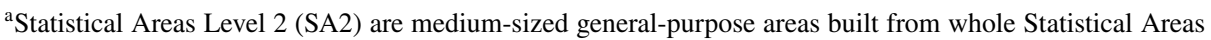
Level 1. Within Australian cities, the SA2s often represent gazetted suburbs. Data from only the inner and middle Melbourne suburbs were included in this analysis

${ }^{\mathrm{b}}$ Car ownership significantly higher than reported member average in respective area category

\section{Applying socio-demographic adjustments}

As described in Table 1, members were more likely to be younger, not have children, high-income full-time workers compared to non-members. Given these characteristics, the difference in car ownership between members and an unadjusted sample of nonmembers (Table 2, column 4 vs column 6) could be partially attributable to socio-demographic differences between the groups. Certain socio-demographic groups (e.g. households with families) are more inclined to be car owners than others (Holtzclaw et al. 2002). To control for this, socio-demographic weights were calculated and applied to the non-member respondent database to align it with the member database. Although member and non-member sample distributions were significantly different on multiple accounts (see discussion of Table 1), the socio-demographic weights were calculated on the basis of age. gender and household typology. Given a sample size of 290 for non-members, adding more factors to the weighting methodology was not considered feasible.

The average car ownership for the adjusted sample was significantly higher than the member average (Mann Whitney U Test, $p=0.000$ ), but lower than the unadjusted nonmember sample. This indicates that socio-demographic and geographic bias needs to be accounted for when comparing car share members and non-members. Differences in car ownership between members and non-members were larger in middle Melbourne than in inner Melbourne. 


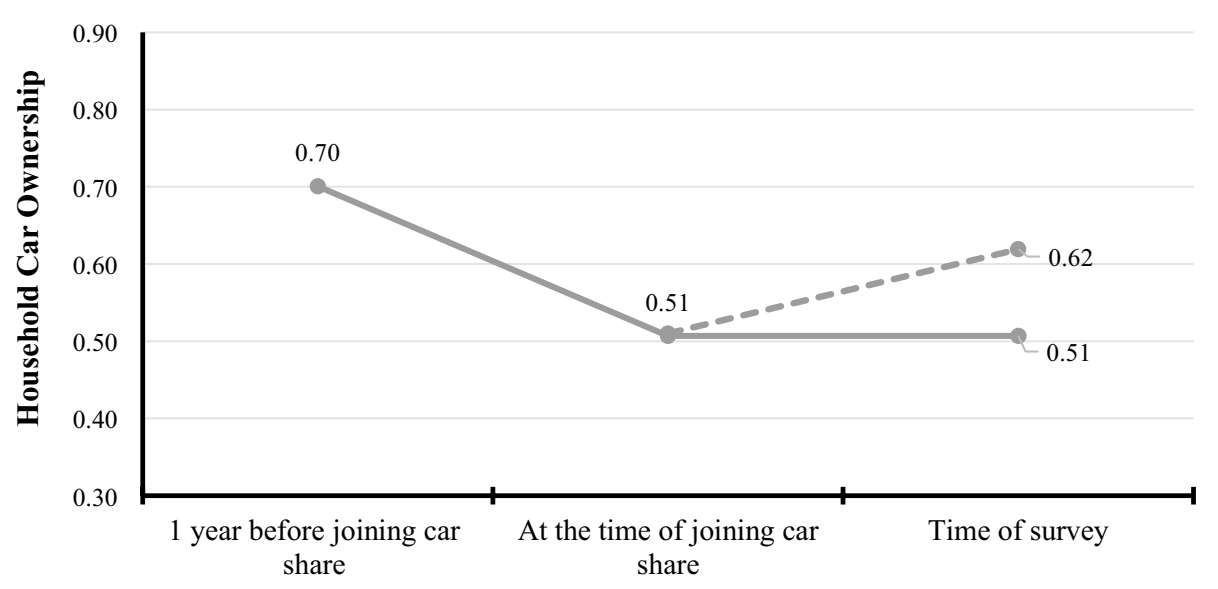

Time point

Actual change

If car puchases were not forgone

Fig. 2 Change in car ownership levels for all car share member respondents $(n=651)$

\section{Study 2- Comparing car ownership of members, before and after joining car share}

Figure 2 plots the average private car ownership per household for car share members $(n=651)$ at the three time-points: one year before joining car share $(0.70)$; joined car share (0.51), and; time of survey (0.51). The reduction of 0.19 cars per household, between the first two time points, was statistically significant (Wilcoxon Signed Rank Test, $Z=-11.225$, $p<0.001)$ ). There was no difference in average car ownership between the time of joining car share and the time of the survey. While there was slight decrease in the number of one, three and four car households $(0.9 \%, 0.3 \%$ and $0.2 \%$ respectively), the number of zero car and two car households went up by $0.2 \%$ and $1.2 \%$ respectively. Therefore, although there was some reorganisation in the distributions of households by car ownership between the time of joining car share and the time of survey, the total number of cars owned by the 651 member households was 330 at both points of time, leading to the average HH car ownership of 0.51 .

Respondents who had no change in car ownership between the time of joining and the survey were asked if they would have increased car ownership if car share was not an option, and forgone car purchases were computed as 0.11 per household. To avoid doublecounting, households that had sold their car prior to joining car share were not included in the calculation of forgone purchases. Forgone purchases were subtracted from the current car ownership levels to compute the full impact of car share on car ownership. Including forgone purchases, total net reductions in car ownership amounted to 0.3 cars per household, i.e. one in three car share member households had sold or forgone a car purchase. In the absence of car share, additional car purchases would have eroded nearly half of the net reductions in car ownership of member households (see Fig. 2).

Figure 2 does not explicitly account for delays in car purchase and it is possible that some respondents who reported forgone purchases had just postponed their car purchase. Net reductions were likely to occur before joining car share, and there were no net reductions in car ownership since joining car share. 


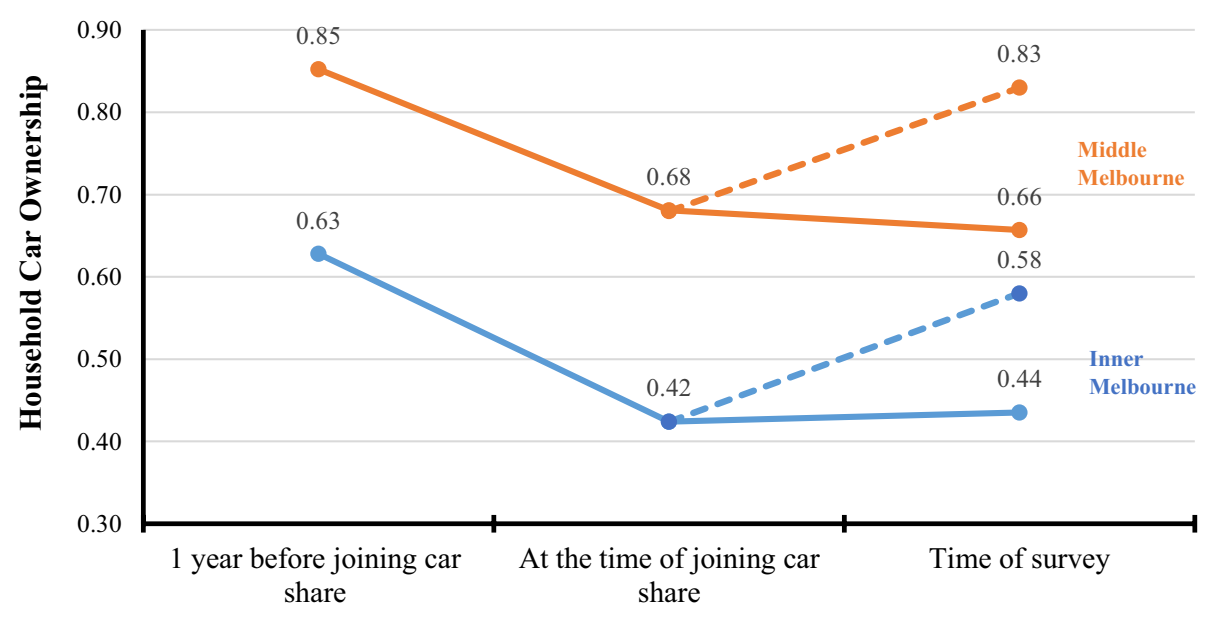

Time Point

Actual change

-ேーーーーーー・ If car purchases were not forgone

Fig. 3 Change in car ownership for car share members, inner and middle Melbourne $(n=651)$

\section{Comparing inner and middle Melbourne}

Member respondents from both inner $(n=441)$ and middle Melbourne $(n=210)$ reported a significant net reduction in car ownership in the period prior to joining car share (Wilcoxon Signed Rank Test, For Inner: $\mathrm{Z}=-9.487, p<0.001$; For Middle $=\mathrm{Z}=-6.000, p<0.001$ ) (Fig. 3). One year prior to joining car share, inner Melbourne respondents had fewer cars per household (0.63) compared to middle Melbourne (0.85). After joining car share, household private car ownership did change. Members in inner Melbourne reported a net increase of $0.02(0.42-0.44)$ but this increase was not statistically significant (Wilcoxon Signed Rank Test, $\mathrm{Z}=-0.590, p=0.555)$. Members in middle Melbourne reported a net decrease of $0.02(0.68-0.66)$, but this decrease was not statistically significant (Wilcoxon Signed Rank Test, $\mathrm{Z}=-0.480, p=0.631)$.

It is notable that although the average car ownership level is higher in middle Melbourne than in inner Melbourne, members in both areas reported an average car saving (including all net changes in car ownership, including forgone purchase) of 0.3 , that is one in three car sharing household sold or avoided a car purchase.

In the absence of car share, most of the reported net reductions in car ownership would have been eroded due to additional car purchases. In understanding these changes across this period, it is important to consider the possibility of simultaneity bias (see Mishra et al. 2015). One possibility is that the reduction in cars in the year prior to joining car share coincides with life events where car share was an enabler, rather than the main reason for reducing car ownership (discussed in detail by Jain et al. 2020).

\section{Comparing fleet-based and P2P car share members}

Figure 4 presents the change in car ownership for respondents who were members of fleetbased car share $(n=237)$, P2P car share $(n=317)$ and both types of car share $(n=97)$. 


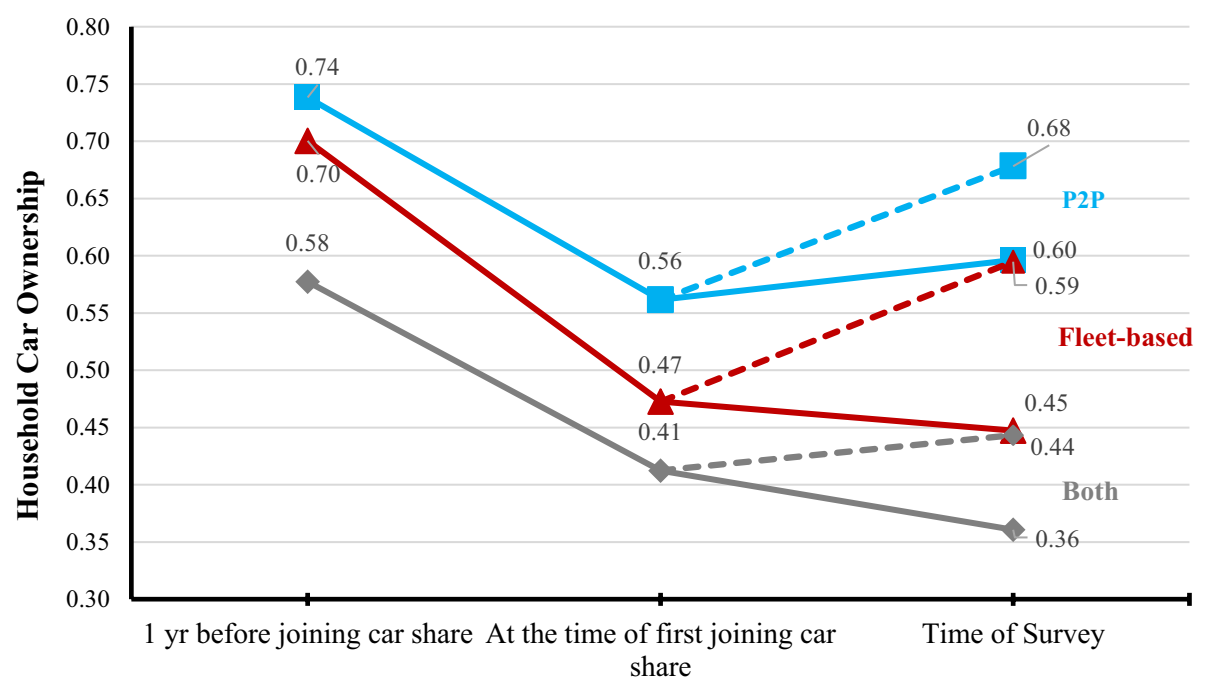

Time Point

Actual change

If car purchases were not forgone

Fig. 4 Change in car ownership for car share members, for P2P $(n=317)$, fleet-based $(n=237)$ and both type $(n=97)$ of operators

Reduction in car ownership was most pronounced for fleet-based car share with an overall reduction of 0.25 cars per $\mathrm{HH}$, i.e. one in four $\mathrm{HH}$ experiencing a net reduction, including car ownership changes in the year prior to joining car share. P2P members had the highest average car ownership levels, yet experienced the smallest overall reduction of 0.14 cars per $\mathrm{HH}$. Members of both services had the lowest household car ownership levels, and experienced a net reduction of 0.22 cars per $\mathrm{HH}$.

Like in case of Sect. 6.2 and 6.2.1, car ownership changes in the year prior to joining car share and the period of time after joining car share were analysed. All categories of members experienced a significant reduction in $\mathrm{HH}$ car ownership in the year prior to joining car share (Wilcoxon Signed Rank Test- Fleet: $Z=-7.348, p<0.001$; P2P: $Z=-7.483, p<0.001$; Both: $\mathrm{Z}=-4.000, p<0.001)$. This is the time period in which majority of the net reduction in car ownership occurred. The actual net change in car ownership since joining car share was much smaller in comparison and statistically insignificant (Wilcoxon Signed Rank Test- Fleet: $Z=-0.657, p=0.511$; P2P: $\mathrm{Z}=-1.648, p=0.099$; Both: $\mathrm{Z}=-1.091, p=0.275)$. After joining car share, members of fleet-based and both type of operators only experienced a small further net reduction in car ownership (0.03 cars per $\mathrm{HH}$ and -0.05 cars per $\mathrm{HH}$ respectively). $\mathrm{P} 2 \mathrm{P}$ members experienced a small net increase of 0.03 cars per $\mathrm{HH}$.

In the absence of car share, all category of members would have experienced a net increase in car ownership (i.e. forgone purchases) eroding the benefits of most of the net actual reductions in car ownership. For fleet members, forgone purchases were 0.15 cars per $\mathrm{HH}$; for $\mathrm{P} 2 \mathrm{P}$ members, 0.08 cars per $\mathrm{HH}$ and for members of both type of operators 0.08 cars per $\mathrm{HH}$. 


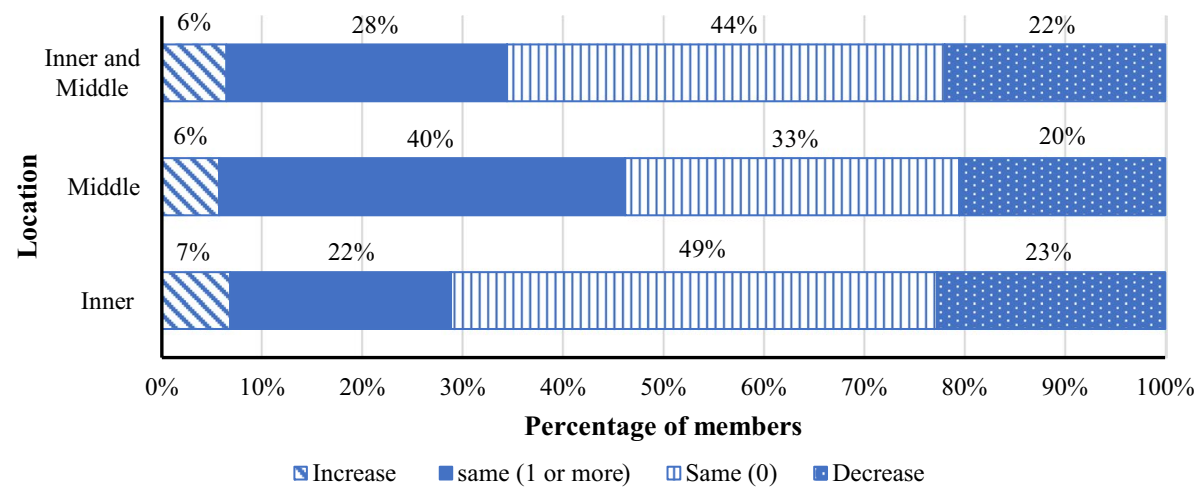

Fig. 5 Range of impacts on car ownership, from the year prior to joining car share until the time of survey; by residential location

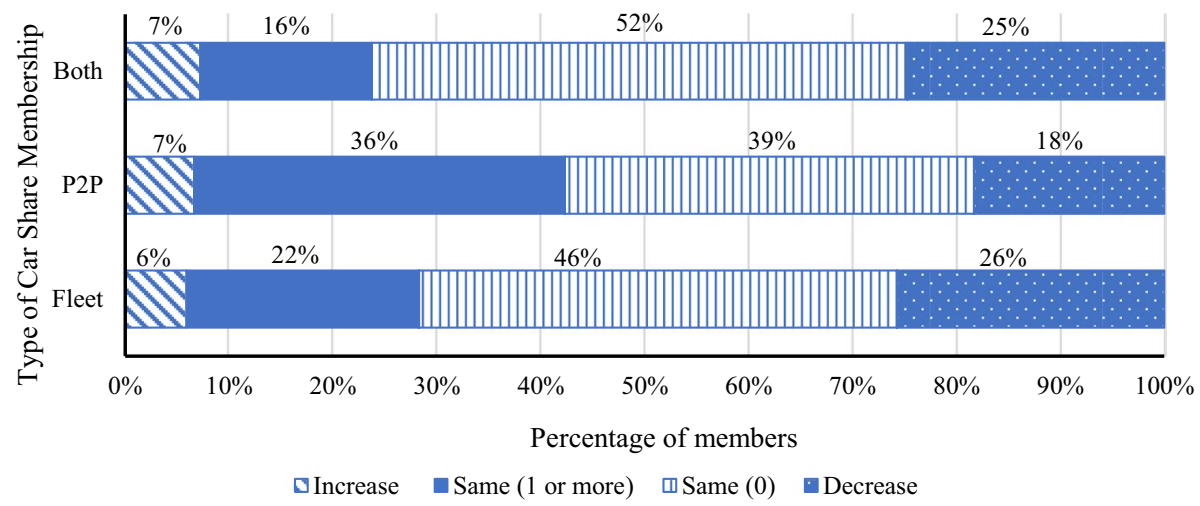

Fig. 6 Range of impact on car ownership, from the year prior to joining car share until the time of survey; by type of car share membership

\section{Variability in impacts on car ownership}

While understanding net changes in average car ownership is valuable, it is crucial to examine the underlying range of impacts. Members were classified into four categories based on their net change in car ownership (including the year prior to joining car share). Figure 5 summarises how car share member households change car ownership from one year prior to joining car share until the time of the survey, not including forgone purchases.

Respondents who were members of fleet-based car share (26\%) and both types of car share $(25 \%)$ and were more likely to reduce car ownership than the P2P members (18\%) (Fig. 6). Most P2P members (75\%) reported no change in car ownership, as compared to nearly a third of fleet-based members (68\%) and members of both services (68\%). Percentage of members increasing car ownership was nearly equal for all three categories. These figures do not include forgone purchases, only actual changes in car ownership. 


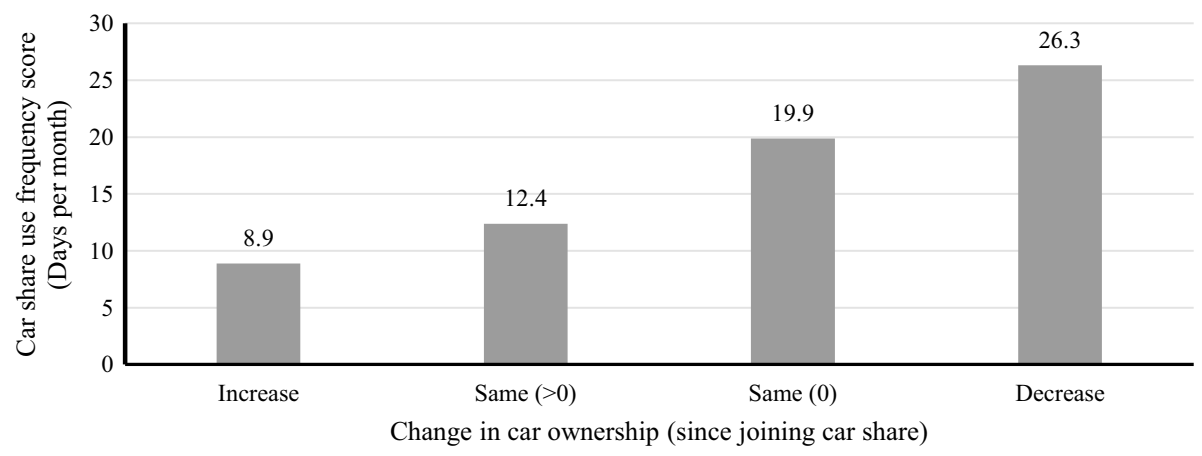

Fig. 7 Frequency of use of car share, across member categories $(n=651)$

\section{Car share use frequency and changes in car ownership}

Next, members were classified into four categories based on reported changes in car ownership since joining car share and included: a net increase in car ownership;net reduction in car ownership; no change in existing car ownership (same $(>0)$ ); and, households that maintained zero car ownership (same (0)). Self-reported car share usage frequency was converted to a frequency score. ${ }^{4}$ Figure 7 shows the frequency of car share use by member category and highlights that frequent users of car share were more likely to report a reduction in car ownership.

The relationship between car ownership and car share use is not clear. It may be that reduced ownership is because of frequent car share use. Alternatively reduced car ownership and frequent car share use may be related to changes in personal circumstances or attitudes towards mobility in general. Nevertheless, future car share studies need to consider this interrelationship. For example, inactive car share members should be excluded from data analysis as their responses will dilute the reported benefits of car share for active users. In this study, inactive car share members (those who had not made a booking in the past year) were excluded from the analysis. Hence, the results only apply to active members. Similarly, frequent users of car share should not be over-represented as this may exaggerate the benefits of car share.

\section{Future changes in car ownership}

While car share members undergo a net reduction in car ownership, most of these changes occurred in the year prior to joining car share. It is therefore relevant to unpack whether members have decided not to purchase a car, or if the purchase has been delayed. To explore this, all respondents were asked if they planned to increase their car ownership at some point in the future (Table 3). In zero car households, some people were planning to purchase a case within the next year, notably, it was the car share members (16\%), whereas none of the non-members had plans to buy a car within the year.

\footnotetext{
4 The frequency score was equivalent to the number of days per month car share was used. For example, for someone who used car share "3-4 days a week", the car share use frequency score was $3.5 \times 4$ weeks a month $=14$.
} 


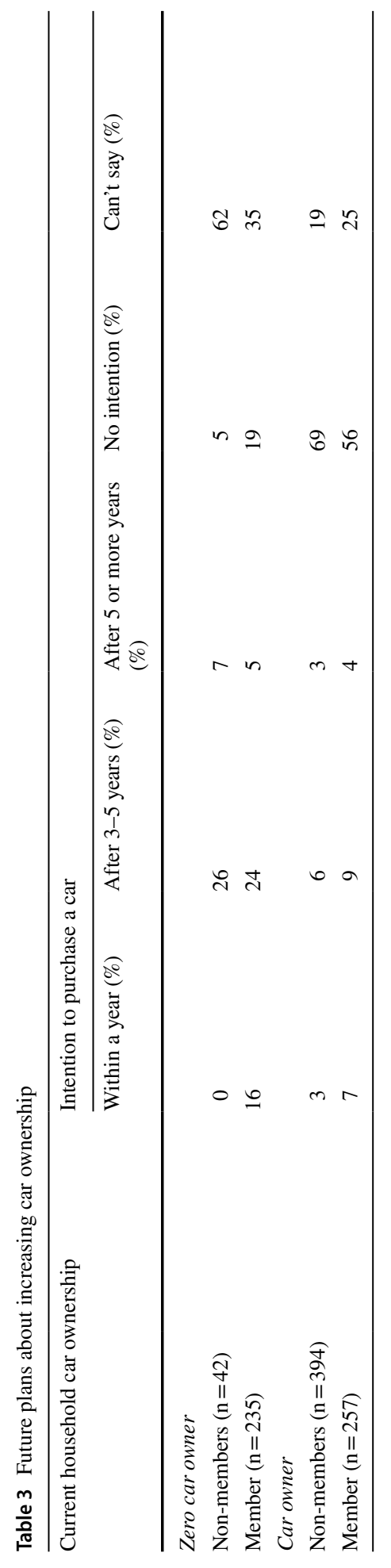


It is possible that zero-car owner car share members aspired to own a car and used car share to delay purchase. Among car owners, members were more likely to have a definite plan for a car purchase, in the near future, than the non-members. A large proportion of respondents were uncertain about their future choices. While a forced response could have required respondents to make a best guess of their future decision, they were probably undecided. These findings identify an important consideration for car share operators and policymakers: what action or support is needed to support the continuation of a zero or low-car ownership lifestyle by car share members? Future studies should explore potential mobility trajectories of car share members and barriers to limiting future car acquisition decisions.

\section{Discussion and conclusion}

This research has enriched understanding of the role of car share in reducing car ownership. Even after accounting for socio-demographic and geographic differences, car share members owned significantly fewer cars than non-members. One in three car share members had sold or forgone the purchase of a car. While the results are similar to trends identified in other international studies (Martin and Shaheen 2011a; Nijland and van Meerkerk 2017), this study provided a more nuanced understanding of car ownership impacts of car share.

Previous studies into car share typically focussed on car ownership change since the time of joining car share and forgone car purchases (Martin and Shaheen 2011a; EngelYan and Passmore 2013). This study was informed by qualitative insights from Jain et al. (2020), who reported that many members sold their private cars prior to joining car share. In many cases, it was the low utilisation (awareness of high fixed costs) of their private car which led them to consider car share and then prepare for that by selling an older or less utilised vehicle. Hence, this study included reductions in car ownership in the year prior to joining car share. Therefore, the reported changes in car ownership included (1) the net change in car ownership in the year prior to joining car share, (2) the net change in car ownership since joining car share and (3) forgone car purchases.

A large proportion of "net" reductions in car ownership took place in the year prior to joining car share. "Net" reductions in car ownership since joining car share were not significant. This contrasts with international studies which report a sizeable decline in car ownership of car share members between the time of joining car share and the time of survey (Katzev 2003; Martin and Shaheen 2011a; Martin et al. 2010; Stasko et al. 2013; Lane 2005). Forgone purchases also formed an important component of limiting car ownership. This concurs with other studies which have reported that the percentage of car share members forgoing a car purchase is often larger than the proportion of people reducing car ownership (Katzev et al. 2001; Millard-Ball 2005; Cervero 2003,1997).

According to the qualitative segment of this research published in Jain et al. (2020), reasons for the reduction in car ownership in the year prior to joining car share included cases where the private car is written off due to a crash, or a large insurance or service premium due or moving to a new city. Such circumstances allowed people to try car share and learn more about it. Similarly, respondents forgoing the purchase of an additional car after joining car share also experienced car share. These findings concur with the results of a recent stated preference study based in Australia which reported that people who have an 
experience of car share are more likely to reduce or forgo car ownership than the general population (Zhou et al. 2020).

This study sheds new light on how car ownership changes associated with car share can vary by geographic location. In contrast to the perception that car share works well in inner-city areas (Celsor and Millard-Ball 2007), this research highlighted that net changes in car ownership for inner, and middle Melbourne members were similar. In both areas, one in three-member households had sold or forgone the purchase of a private car. These findings differ from the experience in San Francisco, where inner-city members reported a significant reduction in car ownership, but the suburban members did not (Clewlow 2016). While net differences in Melbourne were similar in inner and middle Melbourne, there was a considerable variation in the range of impacts across members. While inner Melbourne residents primarily used car share to maintain a zero-car lifestyle, middle Melbourne residents generally used it to avoid the purchase of an additional car. Currently, over two-thirds of Melbourne's shared cars are located in the inner suburbs (within about $10 \mathrm{~km}$ of the central business district). Supply of shared cars in the lower density middle suburbs is limited by a range of factors, underpinned by a perception of limited demand and benefits (Jain 2020). Barring the work of Meelen et al. (2019) in the Dutch context, socio-political and technical barriers to expansion of car share have not been explored. Since this study proves the utility of car share in limiting car ownership in a wider geographic context, future studies should aim to uncover the barriers to expanding car share outside dense inner-city settings. The results do, however, suggest that policymakers can look beyond inner-city areas for opportunities to reduce car ownership and use by supporting the availability of car share.

This study also responds to the lack of empirical studies comparing the impacts of fleetbased and P2P car share systems. A recent study from Portland, USA, reported that 43 per cent of P2P members agreed that they would have bought an additional car in the absence of car share (Dill et al. 2017). However, it is not clear how this compares with fleet-based members in Portland. In Melbourne, fleet-based car share members reported a larger "net" reduction in car ownership than $\mathrm{P} 2 \mathrm{P}$ members. These differences are likely to be explained by the differences in membership and usage characteristics of the two types of services. $\mathrm{P} 2 \mathrm{P}$ car share membership is free and has no ongoing membership fee, unlike most membership options in fleet-based car share. P2P members made fewer bookings per year than fleet-based users, and it is likely that people who continue to pay monthly membership fees for fleet-based car share systems are more inclined to use these systems regularly. There is clear value in examining the impacts of different types of car share systems separately. Fleet-based car share is highly dependent on local government assistance in the form of supportive policy, allocation of parking spaces and in some cases subsidies, while P2P services require minimal government assistance. Analysis that combines the two systems is likely to dilute the benefits of fleet-based systems. Separate assessment of impacts for the two systems is crucial to inform public policy. Further research would help to determine whether these findings are applicable to other major Australian cities and comparable international cities.

Frequency of car share use was related to car ownership as more frequent car share users reported a reduction in car ownership. Analysis of future plans revealed that carowning members are less likely to increase car ownership compared to non-members. On the other hand, non-car owning members are more likely to buy their first car than nonmembers. These insights reveal potential differences in attitudes between members and non-members. Awareness of these differences is important to allow for finessing of policy setting regarding car share. The knowledge about psycho-social determinants of car share 
adoption is growing rapidly (Jain et al. in press) and this knowledge can further help in encouraging the adoption of car share, and reducing car ownership rates.

There are clear messages for policy makers and car share operators regarding harnessing car share to minimise private car ownership. First, car share is more effective at helping people maintain low levels of car ownership, rather than reverse high car ownership (i.e. selling off a private car). Second, car share operators should aim to market their services to people who are undergoing life events which are likely to precipitate selling a car. "Discovering" car share in a short period of carelessness can be an effective way of bypassing the need to overcome the car ownership inertia (Clark et al. 2016; Jain et al. 2020). Third, it is imperative that car share is spatially, temporally and technologically accessible to as many people as possible, because those who give car share a try are potentially likely to continue to use it if they need to access a car, rather than purchasing a private car. Fourth, car share operators and local governments should find ways to operationalise car share beyond inner city settings, where they can potentially limit the acquisition of a second or third car by households. Fifth, P2P car share and fleet-based car share should not be regarded as equivalent by policy makers. The two systems are very different in terms of operations and impact. Given that the financial hurdle to operationalise a P2P car is lower than a fleet-based car, their role in improving car share availability in lower density areas (such as Middle Melbourne) should be recognised. Future studies should also explore the action or support needed to support the continuation of a zero or low-car ownership lifestyle by car share members.

Since conducting this study, the COVID-19 global pandemic has increased awareness of the contamination of public surfaces and the risk of infection (World Health Organization 2020). We can anticipate that this may negatively impact people's willingness to use a shared car. It is not known what additional cleaning or costs may be incurred by car share operators and this will impact underlying business models, user attitudes or use. Future studies are required to fully understand how car share, and other shared modes in general, will continue to impact mobility choices following the coronavirus.

\section{Appendix A}

See Table 4. 


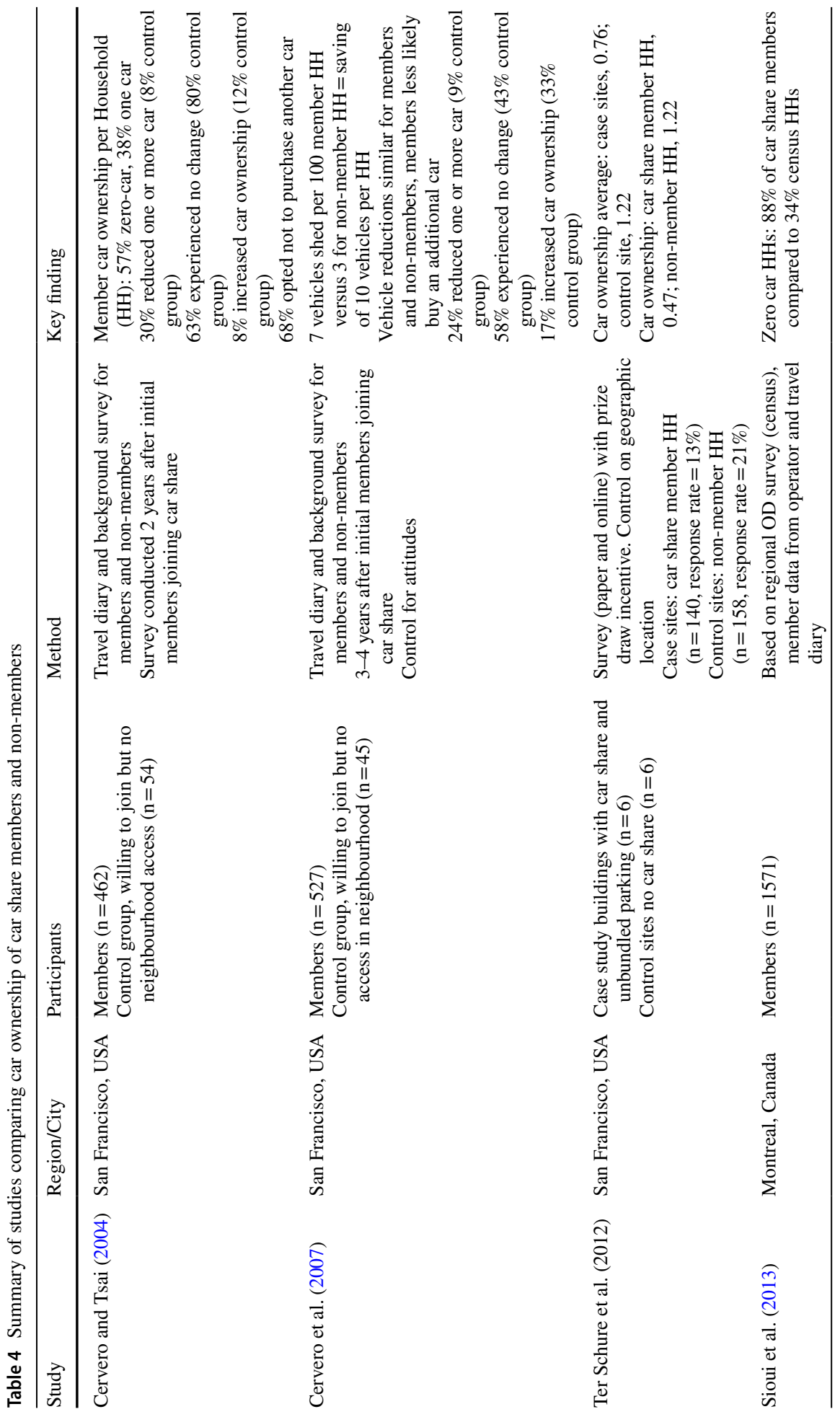




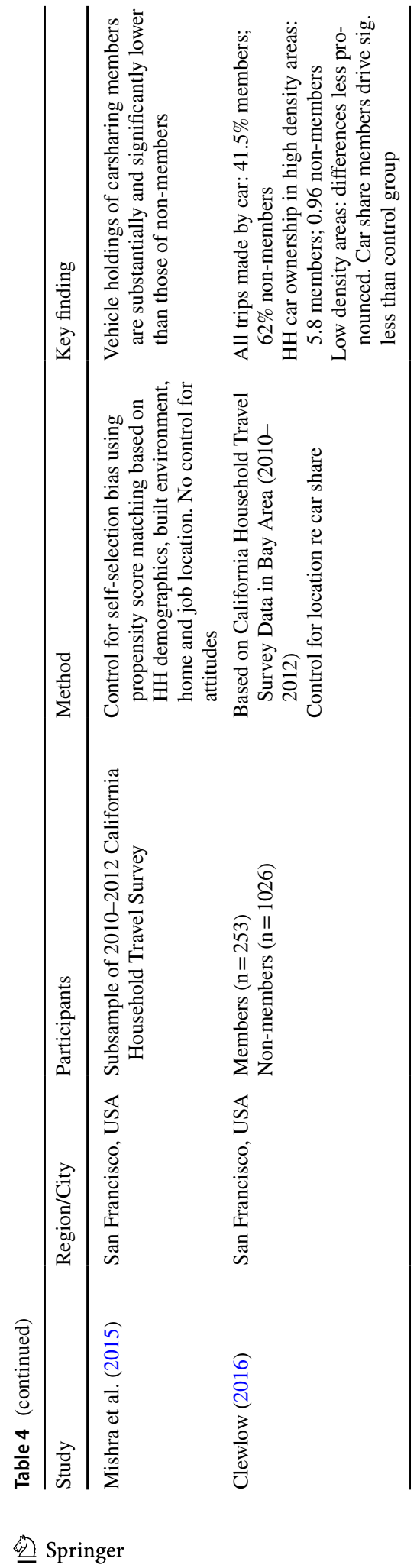




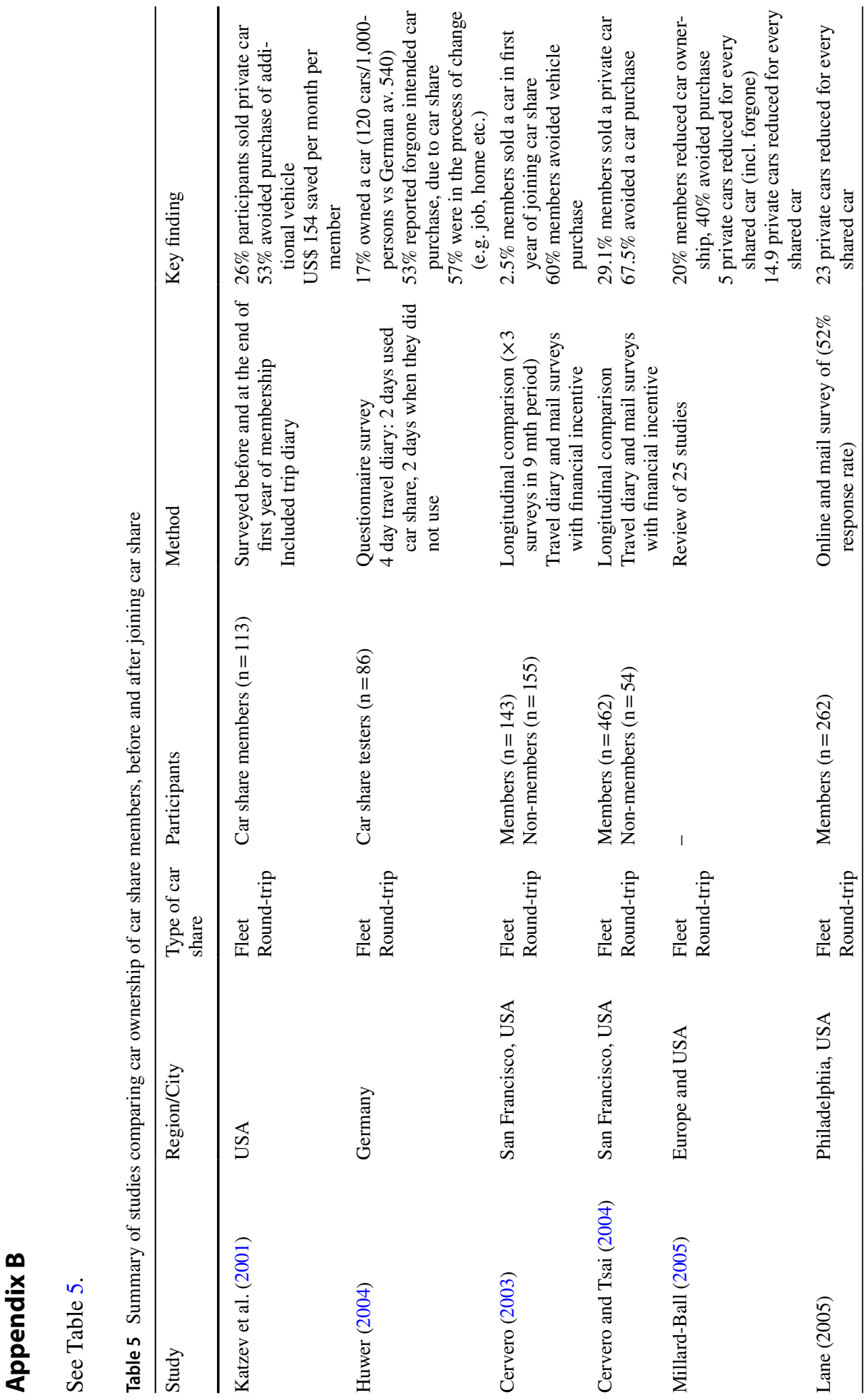




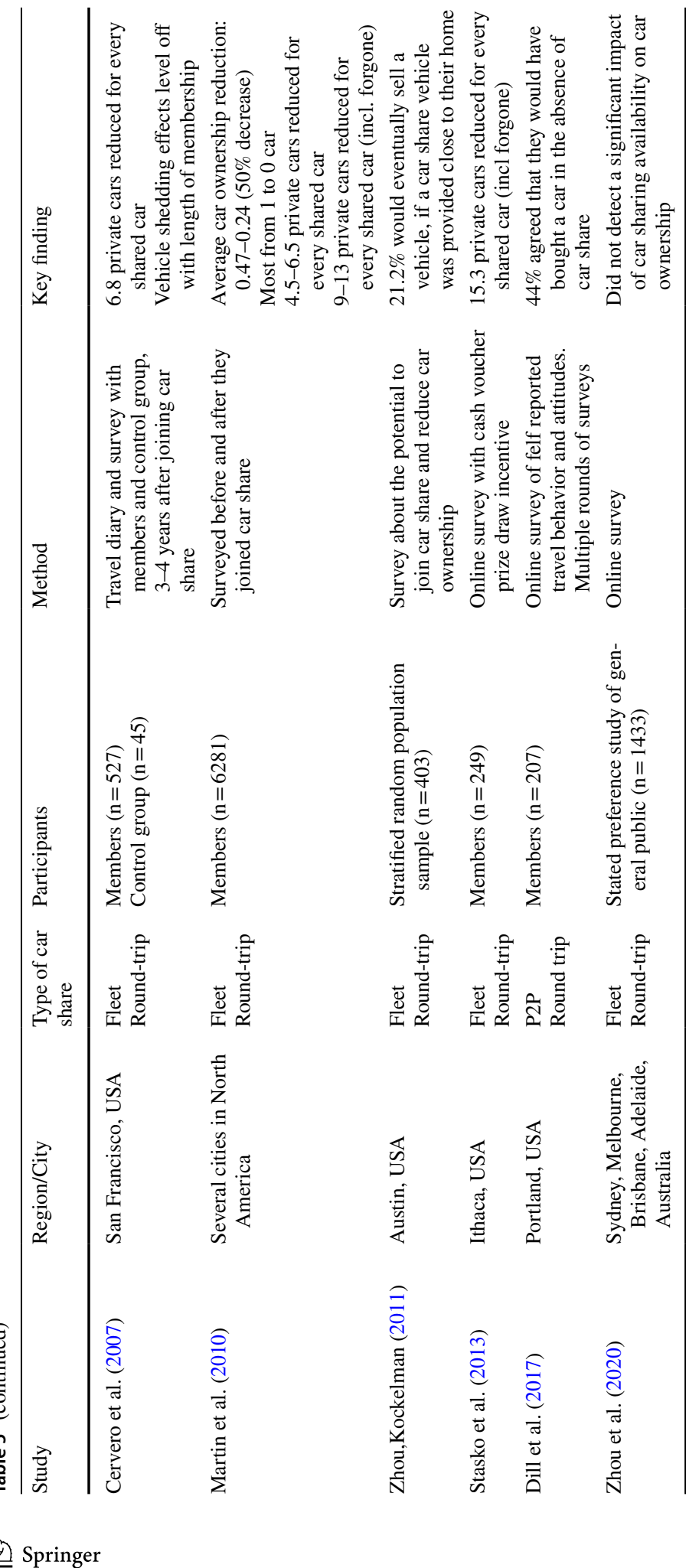


Acknowledgements We are deeply grateful to City of Port Phillip and three-car share operators in Melbourne for helping us with the recruitment of survey participants. We also thank the participants of our survey for their time and insights for our study.

Authors' contributions Taru Jain: Conceptualisation, methodology, formal analysis, investigation, writing - original draft, writing- review and editing, project administration Geoff Rose: Conceptualisation, methodology, writing- review and editing Marilyn Johnson: Conceptualisation, methodology, writing- review and editing.

Funding Funding for this study was received from the Department of Transport, Victorian State Government, Australia, as part of the Sustainable and Effective Public Transport Graduate Research Industry Partnership which supported doctoral studies by the main author.

Availability of data and material Not available publicly as research is continuing.

\section{Compliance with ethical standards}

Conflict of interest The author(s) declare no conflict of interest.

\section{References}

Becker, H., Ciari, F., Axhausen, K.W.: Comparing car-sharing schemes in Switzerland: user groups and usage patterns. Transp. Res. Part A-Policy Pract. 97, 17-29 (2017). https://doi.org/10.1016/j.tra.2017.01.004

Bureau of Infrastructure and Regional Development (BITRE): Traffic and congestion cost trends for Australian capital cities. In: Development, D.o.I.a.R. (ed.). (2015)

Burkhardt, J., Millard-Ball, A.: Who Is attracted to carsharing? Transp. Res. Rec. J. Transp. Res. Board 1986, 98-105 (2006). https://doi.org/10.3141/1986-15

Car Next Door: Car share data for Melbourne. In. (2017)

Celsor, C., Millard-Ball, A.: Where does carsharing work?: Using geographic information systems to assess market potential. Transp. Res. Rec. J. Transp. Res. Board 1992, 61-69 (2007). https://doi. org/10.3141/1992-08

Cervero, R.: Paradigm shift: from automobility to accessibility planning. Urban Fut (Canberra) 22, 9 (1997)

Cervero, R.: City Carshare: First-Year Travel Demand Impacts. Transp Res Rec 1839, 166 (2003)

Cervero, R., Tsai, Y.: City carshare in San Francisco, California—second-year travel demand and car ownership impacts. Transit Plann. Dev. Manag. Perform. Market. 1887, 117-127 (2004)

Cervero, R., Golub, A., Nee, B.: City carshare: longer-term travel demand and car ownership impacts. Transp. Res. Rec. J. Transp. Res. Board 1992, 70-80 (2007). https://doi.org/10.3141/1992-09

Clark, B., Lyons, G., Chatterjee, K.: Understanding the process that gives rise to household car ownership level changes. J. Transp. Geogr. 55, 110-120 (2016). https://doi.org/10.1016/j.jtrangeo.2016.07.009

Clewlow, R.R.: Carsharing and sustainable travel behavior: results from the San Francisco Bay Area. Transp. Policy 51, 158-164 (2016). https://doi.org/10.1016/j.tranpol.2016.01.013

de Lorimier, A., El-Geneidy, A.M.: Understanding the factors affecting vehicle usage and availability in carsharing networks: a case study of communauto carsharing system from Montreal Canada. Int. J. Sustain. Transp. 7(1), 35-51 (2013). https://doi.org/10.1080/15568318.2012.660104

Dill, J., McNeil, N., Howland, S.: Peer-to-peer carsharing: short-term effects on travel behavior in Portland, OR. In. Transportation Research and Education Center (TREC) (2017)

Efthymiou, D., Antoniou, C.: Modeling the propensity to join carsharing using hybrid choice models and mixed survey data. Transp. Policy 51, 143-149 (2016). https://doi.org/10.1016/j.tranpol.2016.07.001

Engel-Yan, J., Passmore, D.: Carsharing and car ownership at the building scale. J. Am. Plann. Assoc. 79(1), 82-91 (2013). https://doi.org/10.1080/01944363.2013.790588

Flexicar: Car share data for Melbourne. In. (2017)

Goget: Car Share Data for Melbourne In. (2017)

Holtzclaw, J., Clear, R., Dittmar, H., Goldstein, D., Haas, P.: Location efficiency: neighborhood and socio-economic characteristics determine auto ownership and use-studies in Chicago, Los Angeles and San Francisco. Transp. Plann. Technol. 25(1), 1-27 (2002). https://doi.org/10.1080/03081060290032033

Huwer, U.: Public transport and car-sharing-benefits and effects of combined services. Transp. Policy 11(1), 77-87 (2004). https://doi.org/10.1016/j.tranpol.2003.08.002

Jain, T.: Car share: a lever for encouraging sustainable travel behavior. Monash University, Melbourne (2020) 
Jain, T., Johnson, M., Rose, G.: Exploring the process of travel behaviour change and mobility trajectories associated with car share adoption. Travel Behav. Soc. 18, 117-131 (2020). https://doi.org/10.1016/j. tbs.2019.10.006

Jain, T., Rose, G., Johnson, M.: “Don't you want the dream?": Psycho-social determinants of car share adoption. Transp. Res. Part F: Traffic Psychol. Behav. (In Press)

Katzev, R.: Car sharing: a new approach to urban transportation problems. Anal. Soc. Issues Public Policy 3(1), 65-86 (2003). https://doi.org/10.1111/j.1530-2415.2003.00015.x

Katzev, R., Brook, D., Nice, M.: The effects of car sharing on travel behaviour: analysis of carsharing portland's first year. World Transp. Policy Pract. 7(1), 22-28 (2001)

Kitamura, R.: A causal analysis of car ownership and transit use. Transportation 16(2), 155-173 (1989). https:// doi.org/10.1007/BF00163113

Lane, C.: PhillyCarShare: first-year social and mobility impacts of carsharing in Philadelphia, Pennsylvania. Transp. Res. Rec. J. Transp. Res. Board 1927, 158-166 (2005)

Loose, W., Mohr, M., Nobis, C.: Assessment of the future development of car sharing in Germany and related opportunities. Transp. Rev. 26, 365-382 (2010)

Martin, E., Shaheen, S.: The Impact of Carsharing on Household Vehicle Ownership. IDEAS Working Paper Series from RePEc (2011a)

Martin, E.W., Shaheen, S.A.: Greenhouse gas emission impacts of carsharing in North America. IEEE Trans. Intell. Transp. Syst. 12(4), 1074-1086 (2011b). https://doi.org/10.1109/TITS.2011.2158539

Martin, E., Shaheen, S., Lidicker, J.: Impact of carsharing on household vehicle holdings. Transp. Res. Rec. J. Transp. Res. Board 2143, 150-158 (2010). https://doi.org/10.3141/2143-19

Meelen, T., Frenken, K., Hobrink, S.: Weak spots for car-sharing in The Netherlands? The geography of sociotechnical regimes and the adoption of niche innovations. Energy Res. Soc. Sci. 52, 132-143 (2019). https ://doi.org/10.1016/j.erss.2019.01.023

Millard-Ball, A.: Car-sharing: where and how it succeeds, vol. 108. Transportation Research Board, Washington (2005)

Mishra, G.S., Clewlow, R.R., Mokhtarian, P.L., Widaman, K.F.: The effect of carsharing on vehicle holdings and travel behavior: a propensity score and causal mediation analysis of the San Francisco Bay Area. Res Transp Econ 52, 46-55 (2015). https://doi.org/10.1016/j.retrec.2015.10.010

Münzel, K., Piscicelli, L., Boon, W., Frenken, K.: Different business models-different users? Uncovering the motives and characteristics of business-to-consumer and peer-to-peer carsharing adopters in The Netherlands. Transp. Res. Part D Transp. Environ. 73, 276-306 (2019). https://doi.org/10.1016/j.trd.2019.07.001

Nijland, H., van Meerkerk, J.: Mobility and environmental impacts of car sharing in the Netherlands. Environ. Innov. Soc. Trans. 23, 84-91 (2017). https://doi.org/10.1016/j.eist.2017.02.001

Parry, I.W.H., Walls, M., Harrington, W.: Automobile externalities and policies. J. Econ. Lit. 45(2), 373-399 (2007). https://doi.org/10.1257/jel.45.2.373

Shaheen, S., Cohen, A.: Growth in worldwide carsharing: an international comparison. Transp. Res. Rec. J. Transp. Res. Board 1992, 81-89 (2007). https://doi.org/10.3141/1992-10

Shaheen, S., Cohen, A.: Carsharing and personal vehicle services: worldwide market developments and emerging trends. Int. J. Sustain. Transp. 7, 5-34 (2012)

Shaheen, S., Cohen, A.: Innovative Mobility: Carsharing Outlook Carsharing Market Overview, Analysis, and Trends. https://escholarship.org/uc/item/61q03282. Accessed 15 Oct 2020 (2020)

Shaheen, S., Sperling, D., Wagner, C.: Carsharing in Europe and North American: past, present, and future. In. (1998)

Shoup, D.C.: The high cost of free parking. J. Plann. Educ. Res. 17(1), 3-20 (1997)

Sims, R., Schaeffer, R., Creutzig, F., Cruz-Núñez, X., D’Agosto, M., Dimitriu, D., Figueroa Meza, M. J., Fulton, L., Kobayashi, S., Lah, O., McKinnon, A., Newman, P., Ouyang, M., Schauer, J.J., Sperling, D., Tiwari, G.: Transport. In: Climate Change 2014: Mitigation of Climate Change. Contribution of Working Group III to the Fifth Assessment Report of the Intergovernmental Panel on Climate Change [Edenhofer, O., R. Pichs-Madruga, Y. Sokona, E. Farahani, S. Kadner, K. Seyboth, A. Adler, I. Baum, S. Brunner, P. Eickemeier, B. Kriemann, J. Savolainen, S. Schlömer, C. von Stechow, T. Zwickel and J.C. Minx (eds.)]. In. Cambridge, United Kingdom and New York, NY, USA., (2014)

Sioui, L., Morency, C., Trépanier, M.: How carsharing affects the travel behavior of households: a case study of Montréal Canada. Int. J. Sustain. Transp. 7(1), 52-69 (2013). https://doi.org/10.1080/15568 318.2012.660109

Stasko, T.H., Buck, A.B., Oliver Gao, H.: Carsharing in a University setting: impacts on vehicle ownership, parking demand, and mobility in Ithaca, NY. Transp. Policy 30, 262-268 (2013). https://doi.org/10.1016/j. tranpol.2013.09.018 
Ter Schure, J., Napolitan, F., Hutchinson, R.: Cumulative impacts of carsharing and unbundled parking on vehicle ownership and mode choice. Transp. Res. Rec. 2319, 96-104 (2012). https://doi.org/10.3141/2319-11

Van Acker, V., Witlox, F.: Car ownership as a mediating variable in car travel behaviour research using a structural equation modelling approach to identify its dual relationship. J. Transp. Geogr. 18(1), 65-74 (2010). https://doi.org/10.1016/j.jtrangeo.2009.05.006

Zhou, B., Kockelman, K.M.: Opportunities for and impacts of carsharing: a survey of the Austin, Texas Market. Int. J. Sustain. Transp. 5(3), 135-152 (2011). https://doi.org/10.1080/15568311003717181

Zhou, F., Zheng, Z., Whitehead, J., Perrons, R.K., Washington, S., Page, L.: Examining the impact of carsharing on private vehicle ownership. Transp. Res. Part A Policy Pract. 138, 322-341 (2020). https://doi. org/10.1016/j.tra.2020.06.003

World Health Organisation.: Coronavirus disease (COVID-19) advice for the public. Accessed 26 June 2020. https://www.who.int/emergencies/diseases/novel-coronavirus-2019/advice-for-public (2020)

Publisher's Note Springer Nature remains neutral with regard to jurisdictional claims in published maps and institutional affiliations.

Dr Taru Jain is Deputy Director of the Public Transport Research Group at Monash University, Melbourne, Australia. Her research interests are sustainable travel behaviour, travel psychology and new mobility.

Professor Geoffrey Rose is Director of the Institute of Transport Studies in the Department of Civil Engineering, Monash University, Australia. Geoff's research interests cover cycling, walking, travel demand management, and sustainable transport policy.

Dr Marilyn Johnson is a Senior Researcher at the Institute of Transport Studies, in the Department of Civil Engineering, Monash University. Marilyn is also the Research and Policy Manager at the Amy Gillett Foundation. Marilyn's research expertise is in cycling including cyclist safety, cyclist-driver interactions, legislative and policy reform to improve safety for cyclists and electric bike use in Australia. 